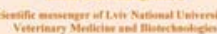
(1) 27 10 incming

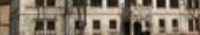

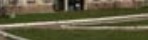

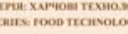
Том 21 Nis 91
Науковий вісник Дьвівського національного університету ветеринарної медицини та біотехнодогій імені С.3. Гжицького. Серія: Харчові технології

\author{
Scientific Messenger of Lviv National University
} of Veterinary Medicine and Biotechnologies.

Series: Food Technologies

UDC 637.03

\title{
The functional features of production of sour-milk product with gluten-free flour
}

\author{
N.V. Bolgova \\ Sumy National Agrarian University, Sumy, Ukraine
}

Article info

Received 11.01.2019 Received in revised form 12.02 .2019 Accepted 13.02.2019

Sumy National Agrarian University, G.Kondratieva Str., 160 Sumy, 40021, Ukraine. Tel.: +38-097-291-88-71 E-mail: bolgova1981@i.ua
Bolgova, N.V. (2019). The functional features of production of sour-milk product with gluten-free flour. Scientific Messenger of Lviv National University of Veterinary Medicine and Biotechnologies. Series: Food Technologies, 21(91), 25-28. doi: 10.32718/nvlvet-f9105

The work substantiates the choice of leaven in order to produce a sour milk product with the most desirable organoleptic characteristics. As a result of the study, the fermentation for yoghurt of Chr. Hansen (Denmark) was selected. These studies determines the choice of scientifically proven methods of fermenta-tion of the following samples. Organoleptic analysis of four samples of dairy products with gluten-free flour was carried out. It was shown that the consistency in each sample was homogeneous and estimated by the tasting commission at 5 points. It was established that the color and smell of samples of the dairy product directly depends on the type of introduced gluten free flour. It is shown that the color in the first and the third samples is estimated at 4 points. The second sample was slightly inferior and was estimated at 3.7 points. The highest score (4.8) was the fourth sample of buckwheat and rice-corn flour. The taste of pure sour milk was present in all abovementioned samples. It was found that the content of buckwheat flour in the first and the second samples gave the product an excessive taste of "porridge". The taste of corn flour was distinguishedly felt in the third sample. It was shown that the first three samples yielded the optimum taste of the fourth to 0.6-1.9 points. It was found that the most balanced is the sour milk sample of the product with buckwheat and rice-corn flour. All organoleptic characteristics were distributed evenly in it. A new technological approach was developed in preparation of the milk-flour mixture to the fermentation. The model of technological process of manufacturing of sour milk product with gluten-free flour is made, which allows to develop technological stages of product production with functional additives. The influence of technological parameters and prescript components on the organoleptic parameters of the dairy product has been established. It was shown that the fermentation of the selected sample proceeds for 8 hours at a temperature of $43 \pm 2{ }^{\circ} \mathrm{C}$. The product is cooled to a temperature of $18{ }^{\circ} \mathrm{C}$ before aseptic packaging. It is recommended to store the ready gluten-free dairy product for 14 days at a temperature of $4-6{ }^{\circ} \mathrm{C}$. Studies conducted show that the developed formula of sour-milk product can be recommended for the production of dairy enterprises.

Key words: fermented milk product, milk and flour mixture, fermentation, titrated acidity, organoleptic evaluation.

\section{Функціональні особливості виробництва кисломолочного продукту 3 безглютеновим борошном}

\author{
Н.В. Болгова
}

Сумський національний агарний університет, м. Суми, Украӥна

У роботі обтрунтовано вибір закваски для отримання кисломолочного продукту з найбільш бажаними органолептичними характеристиками. В результаті дослідження обрано закваску для йогурту фірми Хр. Хансен (Данія). Дані досліджень розглянуто для вибору науково обтрунтованих режимів заквашування наступних зразків. Проведено органолептичний аналіз чотирьох досліджуваних зразків кисломолочних продуктів з безглютеновим борошном. Показано, що консистениія в кожному зі зразків була однорідна та очінена дегустачійною комісією в 5 балів. Встановлено, що колір та запах зразків кисломолочного продукту прямо залежить від виду внесеного безглютенового борошна. Показано, що колір у першому та третьому зразках оцінено в 4 бали. Другий зразок дещо поступався $i$ був оиінений в 3,7 бала. Найвищий бал $(4,8)$ отримав четвертий зразок з гречано-рисовокукурудзяним борочном. Смак всіх розроблених зразків був чистий кисломолочний. Встановлено, що вміст гречаного борочна у 
першому та другому зразках надав продукту надмірний смак “каші”. У третьому зразку сильно відчувався смак кукурудзяного борошна. Показано, щз перші три зразки поступилися оптимальному смаку четвертого на 0,6-1,9 бала. Встановлено, шо найбільш збалансованим є кисломолочний зразок продукту з гречано-рисово-кукурудзяним борочном. В ньому всі органолептичні характеристики розподілилися рівномірно. Розроблено новий технологічний підхід при підготовці молочно-борошняної суміші до сквашування. Складено модель технологічного прочесу виготовлення кисломолочного продукту з безглютеновим борошном, яка дозволяє розробити технологічні етапи виробництва продукту з функціональними добавками. Встановлено вплив технологічних параметрів та рецептурних компонентів на органолептичні показники кисломолочного продукту. Показано, щзо сквашування обраного зразка протікає 8 годин при температурі $\left(43 \pm 2{ }^{\circ} \mathrm{C}\right)$. Перед асептичним фасуванням продукт охолоджують до температури $18{ }^{\circ} \mathrm{C}$. Рекомендовано зберігати готовий безглютеновий кисломолочний продукт 14 діб при температурі 4-6 ${ }^{\circ} \mathrm{C}$. Проведені дослідження показують, щүо розроблена рецептура кисломолочного продукту може бути рекомендована до виробництва підприємствами молочної промисловості.

Ключові слова: кисломолочний продукт, молочно-борошняна суміш, закваска, титрована кислотність, органолептична оиінка.

\section{Вступ}

Здоров'я людини, як підкреслюють численні публікації, перебуває у прямій залежності від харчування. Наукові дослідження в галузі технології, біохімії та біотехнології дозволяють розробити продукти харчування для різних груп населення та регіонів. При цьому враховують стать, вік, фізичні навантаження. Такі продукти можна зарахувати до продуктів функціонального призначення. Вони дозволяють корегувати в раціоні середньостатистичної людини вміст нутрієнтів, підвищувати імунітет та опірність до негативних факторів навколишнього середовища (Bojarskaja et al., 2016; Sukhorska et al., 2017; Klimenkova et al., 2018; Potoroko et al., 2018).

Як відзначали у своїх публікаціях науковці, найбільш популярний i затребуваний сектор функціональної продукції - це кисломолочні продукти (Lebedeva et al., 2015; Palagina et al., 2016; Golubeva et al., 2016; Ababkova \& Novokshanova, 2018). Завдяки високому вмісту живих молочнокислих мікроорганізмів кисломолочні продукти мають безумовний, прогнозований функціональний потенціал. За умови використання певних заквасок виробник отримує можливість виробити продукт 3 пробіотичними властивостями. Крім того, основна маса молочнокислих бактерій, які використовуються як мікрофлора заквасок, в організмі здорової людини живуть постійно й за умови регулярного прийому таких кисломолочних продуктів можуть забезпечувати або підтримувати здоров'я шлунково-кишкового тракту (Novokshanova et al., 2016; Tkachenko, 2016; Behtereva et al., 2017; Grunskaja \& Gabrieljan, 2018).

Варто зазначити, що сучасне наукове товариство паралельно з товаровиробниками успішно займаються розробкою та впровадженням функціональних молочно-зернових комбінованих продуктів для різних категорій населення, зокрема для дитячого, геродієтичного й спеціалізованого харчування (Nekrasov \& Tkachenko, 2014; Romanchuk, 2017; Rudakova \& Narizhnyi, 2017; Dorzhieva \& Suchkova, 2018).

Метою досліджень є обгрунтування доцільності виробництва кисломолочних продуктів 3 безглютеновим борошном.

Для досягнення поставленої мети вирішувалися такі завдання:
- підібрати та обгрунтувати вибір закваски для виробництва кисломолочного продукту 3 безглютеновим борошном;

- вивчити функціонально-технологічні показники розроблених кисломолочних продуктів.

\section{Матеріал і методи досліджень}

Матеріалами дослідження були закваски прямого внесення для кисломолочних продуктів фірми Хр. Хансен (Данія), молоко та безглютенове борошно.

Під час виконання роботи були використані стандартні, загальноприйняті методи досліджень. Відбір проб і пробопідготовку проводили відповідно до ДСТУ 4834:2007 (DSTU 4834:2007, 2008), титровану кислотність визначали за ГОСТ 3624-92 (GOST 3624-92, 2009), органолептичну оцінку проводили відповідно до ДСТУ 4343:2004 (DSTU 4343:2004, 2005).

Для дослідження нами обрано чотири зразки молочно-борошняної суміші: 1-й - гречано-рисова, 2-й - гречано-кукурудзяна, 3-й - рисово-кукурудзяна i 4-й - гречано-рисово-кукурудзяна. Вміст борошна в зразках становив $5 \%$.

\section{Результати та їх обговорення}

Технологія виробництва кисломолочних напоїв передбачає процес сквашування. Для цього нами проведено підбір оптимальної заквасочної композиції, яка дозволить отримати найбільш бажані органолептичні характеристики продукту. Були обрані такі композиції: закваска для йогурту (Streptococcus thermophilus, Lactobacillus delbrueckii subsp. bulgaricus), закваска для сметани (Lactococcus lactis subsp. cremoris, Lactococcus lactis subsp. lactis biovar diacetylactis). Оцінка вибору бажаної закваски проводили на прикладі четвертого зразка. Вміст безглютенового борошна становив 5\%. Суміш пастеризували при температурі $68^{\circ} \mathrm{C}$ з витримкою в 5 хв. Далі іiі охолоджували до температури заквашування. Для йогуртової закваски вона становить $43 \pm 2{ }^{\circ} \mathrm{C}$, а для сметани $-28 \pm 2{ }^{\circ} \mathrm{C}$. Потім суміші ретельно перемішували та залишали у спокої для сквашування на дванадцять годин. Кожну годину проводили візуальний огляд та визначали титровану кислотність. Перше вимірювання провели одразу після заквашування (рис. 1). 


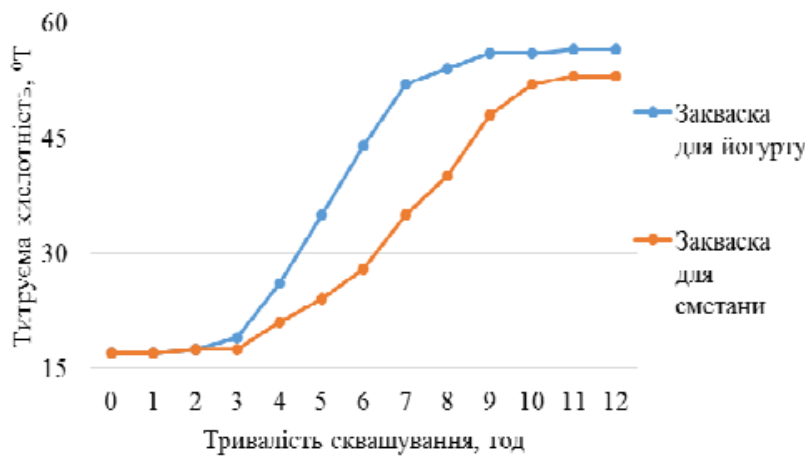

Рис. 1. Графік зміни титрованої кислотності в період сквашування

Аналізуючи графік, бачимо, що активне наростання кислотності у зразка 3 закваскою для йогурту відбувалося перші 8 годин. Далі показник стабілізувався і становив в кінці експерименту $57^{\circ} \mathrm{T}$. Наростання кислотності у другому зразку відбувалося повільніше та більш плавно. Стабілізація кислотності настала через 10 годин сквашування та становила в кінці експерименту $53{ }^{\circ} \mathrm{T}$. Зразок, сквашений закваскою для йогурту, протягом досліджуваного періоду характеризувався приємним кисломолочним смаком, ароматом та привабливим зовнішнім виглядом. Зразок 3 закваскою для сметани мав сторонній вершковий присмак, що властивий сметані. Отже, оптимальна тривалість сквашування для зразка заквашеного йогуртовою закваскою становить 8 годин, а для заквашеного сметановою закваскою 10 год.

Таким чином, у результаті проведених досліджень оптимальною вважаємо заквасочну композицію для йогурту. Відповідно до цього усі наступні досліджувані зразки будуть заквашені цією закваскою.

Після сквашування досліджуваних зразків обраною нами композицією дегустаційна комісія 3 п’яти осіб провела їхню органолептичну оцінку (рис. 2).

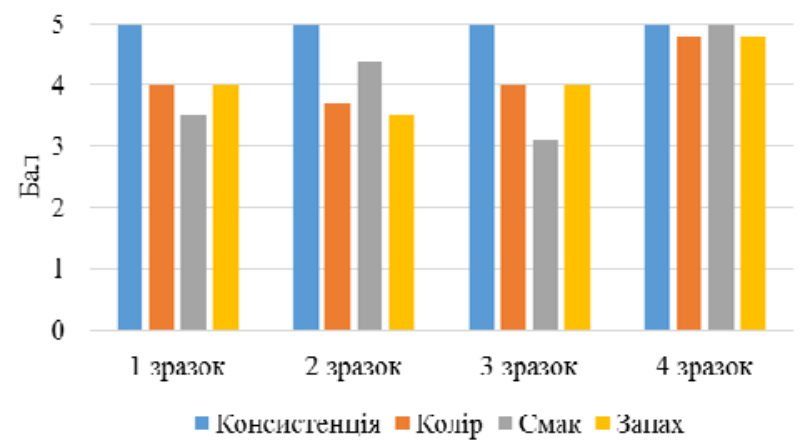

Рис. 2. Органолептична оцінка досліджуваних зразків

Перший зразок мав характерний кисломолочний запах із гречаним відтінком, смак - борошнистий, консистенція однорідна. Колір досліджуваного зразка був обумовлений гречаним борошном та варіював від світло-кремового до кремового. Вміст у даному зразку рисового борошна не вплинув на органолептику. Другий зразок відрізнявся від першого дещо жовтуватим відтінком, який обумовило кукурудзяне борошно. Зразок номер три, з рисовим та кукурудзяним борошном, характеризувався жовтим відтінком, який i обумовлений жовтим кольором кукурудзяного борошна. Четвертий зразок дегустаційна комісія охарактеризувала як найбільш гармонійний за смаком та запахом. Продукт мав рожевий відтінок, смак був характерний, дещо солодкуватий. Переважав запах кисломолочного продукту зі слабким відчуттям кукурудзяного та гречаного борошна. Консистенція всіх розроблених зразків була однорідною, щільною.

Як бачимо 3 отриманих даних, найбільш збалансованим $\epsilon$ кисломолочний зразок продукту 3 гречано-рисово-кукурудзяним борошном. В ньому всі органолептичні характеристики розподілилися рівномірно.

Таким чином, технологія виробництва безглютенового кисломолочного продукту з гречанорисово-кукурудзяним борошном буде складатися 3 таких операцій: приймання та оцінка якості сировини; резервування та охолодження молока; підігрів та нормалізація; внесення борошна, пастеризація молочно-борошняної суміші; охолодження та заквашування, сквашування; охолодження, розлив, реалізація.

Нормалізацію молока проводять до вмісту жиру $3,2 \%$. У підігріте до температури $60{ }^{\circ} \mathrm{C}$ молоко вводять, при постійному перемішуванні, суміш борошна. Після цього проводять пастеризацію суміші при температурі $68{ }^{\circ} \mathrm{C}$ з витримкою в 5 хв. Така послідовність дозволить кисломолочній мікрофлорі ферментувати не лише молоко, а й частково, борошно. Тим самим продукт буде мати вищу засвоюваність. Після пастеризації молочноборошняну суміш охолоджували до температури заквашування (43 $\left.\pm 2 \quad 2{ }^{\circ} \mathrm{C}\right)$ і при постійному перемішуванні вносили закваску фірми Хр. Хансен для йогурту. Сквашування протікало при цій же температурі 8 годин. В кінці сквашування продукт охолоджують до температури $18{ }^{\circ} \mathrm{C}$, ретельно перемішують та фасують в асептичних умовах. Рекомендовано зберігати готовий безглютеновий кисломолочний продукт 14 діб при температурі 4 $6^{\circ} \mathrm{C}$.

\section{Висновки}

Визначено залежність зміни титрованої кислотності зразків від виду використаної молочнокислої мікрофлори заквасок. Дослідили, що використання йогуртової закваски при сквашуванні молочно-борошняної суміші дозволить отримати продукт щільної консистенції 3 бажаними органолептичними та фізико-хімічними властивостям.

На основі органолептичної оцінки представлених зразків продукту доведено, що найбільш гармонійними смаком та запахом характеризується сквашений гречано-рисово-кукурудзяний зразок. 
Рекомендовано зберігати готовий напій при температурі від 4 до $6^{\circ} \mathrm{C}$ до 14 діб.

Перспективи подальших досліджень. Напрямком подальших досліджень може бути вивчення біологічної цінності розробленого кисломолочного напою з безглютеновою борошняною композицією.

\section{References}

Ababkova, A.A., \& Novokshanova, A.L. (2018). Rasshirenie spektra zakvasochnoj mikroflory v tehnologii kislomolochnogo produkta s gidrolizatom syvorotochnyh belkov. Molochnohozjajstvennyj vestnik, 3(31), 71-78. doi: 10.24411/2225-4269-201800022 (in Russian).

Behtereva, M.K., Ivanova, V.V., \& Muhina, N.V. (2017). Kislomolochnye produkty $\mathrm{V}$ pitanii detej: profilakticheskie i lechebnye vozmozhnosti ispol'zovanija. Rossijskij vestnik perinatologii i pediatrii, 2, 22-29. doi: 10.21508/1027-4065-201762-2-22-29 (in Russian).

Bojarskaja, L.A., Vil'ms, E.A., Turchaninov, D.V., Bogdashin I.V., \& Erofeev, Ju.V. (2016). Gigienicheskoe obosnovanie primenenija funkcional'nyh molochnyh produktov $\mathrm{v}$ profilaktike deficita makro- i mikrojelementov. Gigiena i sanitarija, 95(11), 1095-1099 doi: 10.18821/00169900-2016-95-11-1095-1099 (in Russian).

Dorzhieva, N.V., \& Suchkova, E.P. (2018). Tehnologicheskie aspekty proizvodstva sbrozhennogo zernovogo napitka na osnove molochnoj syvorotki. Nauchnyj zhurnal NIU ITMO. Serija "Processy i apparaty pishhevyh proizvodstv", 1, 21-26. doi: 10.17586/2310-1164-2016-11-1-21-26 (in Russian).

DSTU 4343:2004 (2005). Yohurty. Zahalni tekhnichni umovy. Kyiv (in Ukrainian).

DSTU 4834:2007 (2008). Moloko ta molochni produkty. Pravyla pryimannia, vidbyrannia ta hotuvannia prob do kontroliuvannia. Kyiv (in Ukrainian).

Golubeva, L.V., Dolmatova, O.I., \& Ivancova, M.I. (2016). Kislomolochnyj produkt funkcional'nogo naznachenija. Vestnik Voronezhskogo gosudarstvennogo universiteta inzhenernyh tehnologij, 2, 148-152. doi: 10.20914/2310-1202-2016-2-148-152 (in Russian).

GOST 3624-92 (2009). Moloko i molochnye produkty. Titrimetricheskie metody opredelenija kislotnosti. Moskva (in Russian).

Grunskaja, V.A., \& Gabrieljan, D.S. (2018). Mikrobiologicheskie aspekty proizvodstva obogashhennyh kislomolochnyh produktov s ispol'zovaniem molochnoj syvorotki. Molochnohozjajstvennyj vestnik, 3(31), 91-103. doi: 10.24411/2225-4269-2018-00024 (in Russian).

Klimenkova, A.Ju., Stefanova, I.L., Shahnazarova, L.V., \& Mazo, V.K. (2018). Funkcional'nye produkty na osnove jaichnogo melanzha. Voprosy pitanija, 5, 215216. doi: 10.24411/0042-8833-2018-10325 (in Russian).
Lebedeva, U.M., Abramov, A.F., Stepanov, K.M., Vasil'eva, V.T., \& Efimova, A.A. (2015). Pishhevaja cennost' nacional'nyh molochnyh produktov $\mathrm{s}$ dobavleniem lesnyh jagod i dikorastushhih pishhevyh rastenij Jakutii. Voprosy pitanija, 6, 132-140. doi: 10.24411/0042-8833-2015-00071 (in Russian).

Nekrasov, P.O., \& Tkachenko, P.O. (2014). Innovatsiina tekhnolohiia bifidovmisnykh kombinovanykh kyslomolochnykh napoiv funktsionalnoho pryznachennia. Kharchova nauka i tekhnolohiia, 2, 49-56. doi: 10.15673/2073-8684.27/2014.29834 (in Ukrainian).

Novokshanova, A.L., Ababkova, A.A., \& Abramov, D.V. (2016). Rezul'taty poiska optimal'nogo konsorciuma mikroorganizmov pri proizvodstve specializirovannogo belkovogo kislomolochnogo produkta. Vestnik mezhdunarodnoj akademii holoda, 4, 23-29. doi: 10.21047/1606-4313-2016-15-4-23-29 (in Russian).

Palagina, M.V., Bogrjanceva, I.Je., Ponamarev, V.V., \& Fishhenko, E.S. (2016). Obosnovanie razrabotki novyh pit'evyh jogurtov na osnove tehnologii kislomolochnyh napitkov funkcional'nogo naznachenija. Izvestija Dal'nevostochnogo federal'nogo universiteta. Jekonomika i upravlenie, 4(80), 105-113. doi: 10.5281/zenodo.221325 (in Russian).

Potoroko, I.Ju., Pajmulina, A.V., Uskova, D.G., \& Kalinina, I.V. (2018). Nauchnye i prakticheskie aspekty tehnologij produktov pitanija funkcional'noj napravlennosti. Vestnik Juzhno-Ural'skogo gosudarstvennogo universiteta. Serija: Pishhevye i biotehnologii, 1, 49-59. doi: 10.14529/food180106 (in Russian).

Romanchuk, I. (2017). Vykorystannia zernovykh dobavok u vyrobnytstvi molochnykh produktiv Z kombinovanym skladom syrovyny. Zernovi produkty ta kombikormy, 17(3), 27-32. doi: 10.15673/gpmf.v17i3.658 (in Ukrainian).

Rudakova, T., \& Narizhnyi, S. (2017). Fermentatyvnyi metod vyznachennia biolohichnoi tsinnosti molochnykh produktiv iz zernovym inhrediientom dlia dytiachoho kharchuvannia. Zernovi produkty ta kombikormy, 17(2), 24-28. doi: 10.15673/gpmf.v17i2.525 (in Ukrainian).

Sukhorska, O.P., Slyvka, N.B., \& Bilyk, O.Ya. (2017). Analiz osnovnykh roslynnykh dzherel bioflavonoidiv dlia stvorennia produktiv likuvalno-profilaktychnoho pryznachennia. Naukovyi visnyk Lvivskoho natsionalnoho universytetu veterynarnoi medytsyny ta biotekhnolohii imeni S.Z. Gzhytskoho, 19(80), 107110. doi: 10.15421/nvlvet8022 (in Ukrainian).

Tkachenko, N.A. (2016). Zakvashuvalni kompozytsii bakterii dlia tekhnolohii kyslomolochnykh produktiv dytiachoho kharchuvannia. Mikrobiolohiia i biotekhnolohiia, 1, 55-67. doi: 10.18524/23074663.2016.1(33).65371 (in Ukrainian). 